Intisari Sains Medis 2019, Volume 10, Number 1: 247-250

P-ISSN: 2503-3638, E-ISSN: 2089-9084

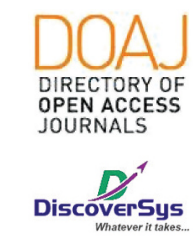

Published by DiscoverSys

\section{Turnaround time pelayanan darah rujukan di bank darah RSUP Dr. Wahidin Sudirohusodo sebelum dan sesudah implementasi sistem informasi manajemen darah}

\author{
Erika Rosaria Simbolon ${ }^{1 *}$, Rachmawati Muhiddin ${ }^{2}$, Mansyur Arif ${ }^{2}$
}

\section{ABSTRACT}

Background: Blood Information Management System or SIMERAH is the system information which allows blood bank officers at Dr. Wahidin Sudirohusodo hospital to check blood supply in Blood Transfusion Unit. Before SIMERAH implementation, referral blood service was done by directly giving the patient's family a blood request form to PMI without blood supply information. Referral blood service after SIMERAH implementation requires blood bank officers to order blood before referring patients to PMI. This study aims to compare Turnaround Time (TAT) of referral blood before and after SIMERAH implementation.

Methods: The population of this study has been all patients receiving referral blood service to PMI since January 2017 to June 2017 (before SIMERAH implementation) and January 2018 to
June 2018 (after SIMERAH implementation). Statistical analysis conducted were descriptive statistics and paired t-test.

Results: The average TAT at Dr. WahidinSudirohusodo Hospital's Blood Bank before SIMERAH implementation was 6,10 hours. The average TAT after SIMERAH implementation was 4,37 hours. There was 25,2\% decrease of average TAT after SIMERAH implementation at Dr. Wahidin Sudirohusodo Hospital's Blood Bank. There were significant decreases of TAT in January, February, March, May, and June $(p<0.05)$. There was a decrease of TAT in April but not statistically significant ( $p>0.05)$.

Conclusion: SIMERAH was significantly decrease TAT in Dr. Wahidin Sudirohusodo Hospital's Blood Bank.

Keywords: PMI, SIMERAH, TAT

Cite This Article: Simbolon, E.R., Muhiddin, R., Arif, M. 2019. Turnaround time pelayanan darah rujukan di bank darah RSUP Dr. Wahidin Sudirohusodo sebelum dan sesudah implementasi sistem informasi manajemen darah. Intisari Sains Medis 10 (1): 247-250. D0I: 10.1556/ ism.v10i1.361

PProgram Pendidikan Dokter Spesialis Ilmu Patologi Klinik FK UNHAS/RSUP Dr. Wahidin Sudirohusodo, Makassar ${ }^{2}$ Departemen IImu Patologi Klinik FK UNHAS/RSUP Dr. Wahidin Sudirohusodo, Makassar

\section{*Korespondensi :} Erika Rosaria Simbolon; Departemen Patologi Klinik FK UNHAS/RSUP Dr. Wahidin Sudirohusodo, Makassar; erikarosariasimbolon@gmail.com

Diterima : 13-11-2018 Disetujui : 20-03-2019 Diterbitkan : 01-04-2019

\section{ABSTRAK}

Latar Belakang: Sistem Informasi Manajemen Darah (SIMERAH) merupakan sistem informasi yang memungkinkan petugas Bank Darah RSUP Dr. Wahidin Sudirohusodo mengetahui persediaan darah di Unit Transfusi Darah (UTD). Pelayanan darah rujukan sebelum implementasi SIMERAH dilakukan dengan secara langsung memberi keluarga pasien formulir permintaan darah ke UTD PMI tanpa informasi ketersediaan darah. Pelayanan darah rujukan setelah implementasi SIMERAH mewajibkan petugas bank darah untuk memesan darah terlebih dahulu sebelum merujuk pasien ke UTD PMI. Penelitian ini bertujuan untuk membandingkan Turnaround time (TAT) darah rujukan sebelum dan sesudah implementasi SIMERAH.

Metode: Populasi penelitian ini adalah seluruh pasien yang mendapat pelayanan darah rujukan ke PMI Januari-Juni 2017 (Sebelum implementasi SIMERAH) dan Januari-Juni 2018 (Sesudah implementasi SIMERAH). Analisis statistik yang digunakan adalah perhitungan statistik deskriptif dan uji-t berpasangan.

Hasil: Rerata TAT Bank darah RSUP Dr. Wahidin Sudirohusodo sebelum menggunakan SIMERAH adalah 6,10 jam dan sesudah menggunakan SIMERAH adalah 4,37 jam. Terjadi penurunan TAT sebesar 25,2\%. Perbandingan TAT berdasarkan bulan menunjukan bahwa terjadi penurunan TAT yang signifikan pada bulan Januari, Februari, Maret, Mei dan Juni $(p<0,05)$. Bulan April terjadi penurunan TAT tetapi secara statistik tidak signifikan $(p>0,05)$ Simpulan: SIMERAH secara signifikan menurunkan TAT Bank darah di RSUP Dr. Wahidin Sudirohusodo.
Kata Kunci: PMI, SIMERAH, TAT

Site Pasal Ini: Simbolon, E.R., Muhiddin, R., Arif, M. 2019. Turnaround time pelayanan darah rujukan di bank darah RSUP Dr. Wahidin Sudirohusodo sebelum dan sesudah implementasi sistem informasi manajemen darah. Intisari Sains Medis 10 (1): 247-250. D0I: 10.1556/ ism.v10i1.361 


\section{PENDAHULUAN}

Sistem Informasi Manajemen darah (SIMERAH) adalah salah satu inovasi Sistem Informasi Rumah Sakit (SIRS) di Bank Darah RSUP Dr. Wahidin Sudirohusodo. SIMERAH memungkinkan petugas bank darah untuk mengetahui persediaan darah di Unit Transfusi Darah (UTD) Makassar. RSUP Dr Wahidin Sudirohusodo sejak bulan Oktober 2017 telah bekerja sama dengan beberapa rumah sakit seperti RSUD Labuang Baji, RSUD Daya, RS Pelamonia, RS Tajuddin Chalid, RS Ibnu Sina, RS Universitas Hasanuddin, dan UTD PMI serta Unit Pelaksana Teknis Daerah (UPTD) Transfusi Dinas kesehatan Provinsi Sulawesi Selatan untuk menjalankan SIMERAH. ${ }^{1,2}$

Rumah Sakit Umum Pusat Dr. Wahidin Sudirohusodo merupakan rumah sakit kelas A yang sudah terakreditasi Komite Akreditasi Rumah Sakit (KARS) dan Joint Comisssion International (JCI). Kasus-kasus sulit yang tidak bisa ditangani di Pemberi Pelayanan Kesehatan (PPK) II akan dirujuk ke RSUP Dr. Wahidin Sudirohusodo, sehingga kasus-kasus yang ada di RSUP Dr. Wahidin Sudirohusodo adalah kasus berat yang memerlukan penanganan komprehensif termasuk kebutuhan transfusi darah. ${ }^{1,3-5}$

Permintaan pelayanan darah di Bank Darah RSUP Dr.Wahidin Sudirohusodo mengalami peningkatan dari tahun ke tahun. Permintaan pelayanan darah pada tahun 2015 ada 14.772 , tahun 2016 ada 16.468 dan tahun 2017 ada 17.631. Tidak semua permintaan darah yang masuk ke Bank Darah RSUP Dr. Wahidin Sudirohusodo dapat dipenuhi oleh bank darah. Menurut laporan Bank Darah RSUP Dr. Wahidin Sudirohusodo jumlah permintaan darah yang dirujuk ke UTD PMI dan UPTD Transfusi Dinas Kesehatan Provinsi Sulawesi Selatan pada tahun 2015 sebanyak 6.633, tahun 2016 sebanyak 19.042 dan tahun 2017 sebanyak 21.045. ${ }^{1,2}$

Di Makassar ada 2 UTD yaitu UPTD Transfusi milik Dinas Kesehatan Provinsi Sulawesi Selatan dan UTD PMI. Jarak UPTD Transfusi Dinas Kesehatan Provinsi Sulawesi Selatan dari RSUP Dr. Wahidin Sudirohusodo sekitar $3 \mathrm{KM}$, sedangkan jarak UTD PMI dari RSUP Dr. Wahidin Sudirohusodo adalah $12 \mathrm{KM}$. Bila menggunakan kendaraan, dibutuhkan waktu sekitar 8 menit untuk perjalanan dari RSUP Dr. Wahidin Sudirohusodo ke UPTD Transfusi Dinas Kesehatan Provinsi Sulawesi Selatan. Waktu yang dibutuhkan untuk perjalanan dari RSUP Dr. Wahidin Sudirohusodo ke UTD PMI adalah 26 menit.

Pada pelayanan darah rujukan sebelum implementasi SIMERAH, keluarga pasien membawa sendiri formulir permintaan darah ke UTD PMI atau UPTD Transfusi Dinas Kesehatan Provinsi Sulawesi selatan tanpa ada informasi ketersediaan darah sebelumnya. Hal ini mengakibatkan keluarga pasien akan bolak balik dari UTD ke rumah sakit. Proses rujukan seperti ini kurang efektif karena selain merepotkan keluarga pasien juga menambah lama Turnaround Time (TAT) bank darah. Pelayanan darah rujukan setelah implementasi SIMERAH mewajibkan petugas bank darah memesan darah terlebih dahulu melalui SIMERAH sebelum merujuk pasien. Setelah ada jawaban /informasi tentang ketersediaan darah di UTD, keluarga pasien akan diberi surat rujukan pengambilan darah ke UTD. ${ }^{1,2}$ Diharapkan SIMERAH dapat mempersingkat TAT darah rujukan dari Bank Darah RSUP Dr. Wahidin Sudirohusodo.

\section{METODE PENELITIAN}

Penelitian ini merupakan penelitian retrospektif dengan mengambil data pada buku laporan Bank Darah RSUP Dr. Wahidin Sudirohusodo dan SIRS. Sampel penelitian adalah pasien yang mendapat pelayanan darah rujukan dari Bank darah RSUP Dr. Wahidin Sudirohusodo ke UTD PMI Kota Makassar pada bulan Januari-Juni 2017 (sebelum implementasi SIMERAH) dan Januari-Juni 2018 (setelah implementasi SIMERAH). Penelitian ini telah mendapatkan persetujuan dari Komisi Etik Penelitian Kesehatan FK-UNHAS-RSUP Dr. Wahidin Sudirohusodo, Makassar.

Sampel penelitian adalah semua data pasien yang mendapat pelayanan darah rujukan ke PMI di Bank Darah RSUP Dr. Wahidin Sudirohusodo Makassar periode Januari - Juni 2017 (sebelum implementasi SIMERAH) dan periode Januari - Juni 2018 (sesudah implementasi SIMERAH). Data sebelum implementasi SIMERAH diambil dari buku laporan darah rujukan di Bank Darah RSUP Dr. Wahidin Sudirohusodo.

Kriteria inklusi penelitian ini adalah seluruh pasien yang yang memesan darah whole blood, Pack Red Cell (PRC) atau Fresh Frozen Plasma ke PMI yang terdaftar dalam pelayanan darah rujukan langsung pakai di Bank Darah RSUP Dr. Wahidin Sudirohusodo Makassar periode Januari Juni 2017 dan Januari - Juni 2018. Kriteria ekslusi adalah pasien dengan data pelayanan darah tidak lengkap. Turnaround Time dihitung berdasarkan rerata jumlah jam per pasien per hari.

Data yang diperoleh diolah dengan menggunakan SPSS versi 22. Analisis statistik yang dilakukan adalah perhitungan statistik deskriptif dan uji-t berpasangan. Hasil uji signifikan jika nilai $\mathrm{P}<0,05$. 
Tabel 1. Gambaran deskriptif nilai TAT

\begin{tabular}{cccc}
\hline Variabel & Rentang & Rerata & SB \\
\hline TAT 2017 (Jam) & $2,13-18,55$ & 6,10 & 2,29 \\
TAT 2018 $(\mathrm{Jam})$ & $1,42-10,40$ & 4,37 & 1,24 \\
\hline
\end{tabular}

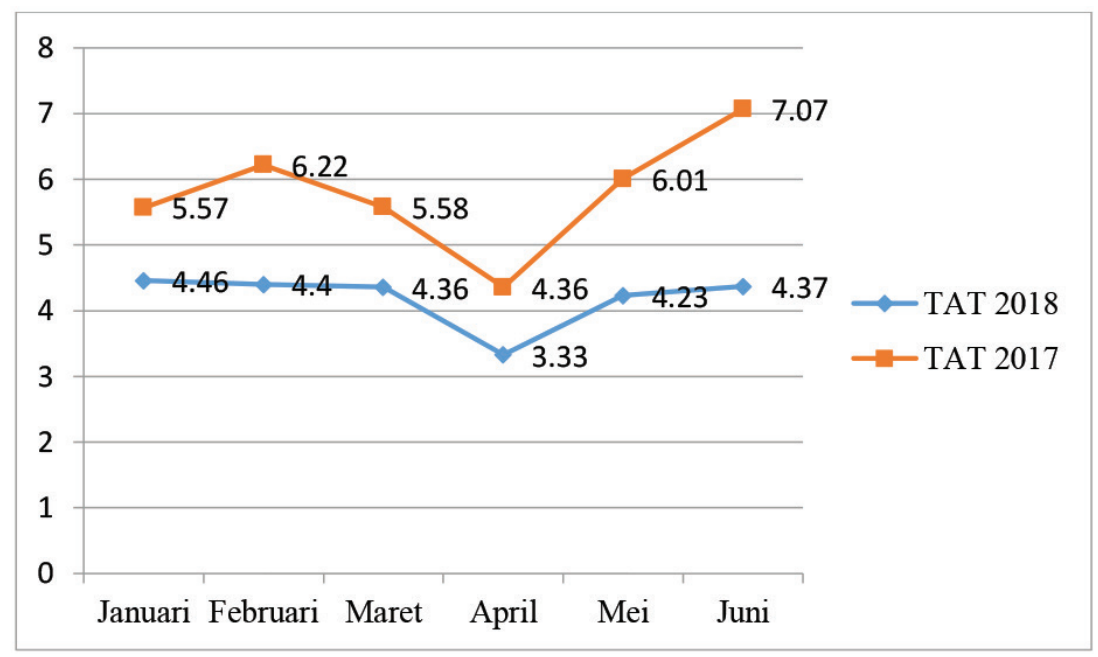

Grafik 1. Perbandingan nilai TAT pada tahun 2017 dan 2018 berdasarkan bulan

Tabel 2. Perbandingan nilai TAT menurut bulan

\begin{tabular}{llccc}
\hline \multicolumn{1}{c}{ Bulan } & TAT (Jam) & Rata-rata & SB & P \\
\hline Januari & Tahun 2017 & 5,57 & 1,55 & $<0,0001$ \\
& Tahun 2018 & 4,46 & 1,33 & \\
\multirow{3}{*}{ Februari } & Tahun 2017 & 6,22 & 4,07 & 0,047 \\
& Tahun 2018 & 4,40 & 2,02 & \\
\multirow{3}{*}{ April } & Tahun 2017 & 5,58 & 1,58 & $<0,0001$ \\
& Tahun 2018 & 4,36 & 1,27 & \\
\multirow{2}{*}{ Mei } & Tahun 2017 & 4,36 & 0,28 & 0,146 \\
& Tahun 2018 & 3,33 & 0,43 & \\
\multirow{2}{*}{ Juni } & Tahun 2017 & 6,01 & 1,34 & $<0,0001$ \\
& Tahun 2018 & 4,23 & 1,51 & \\
\multirow{2}{*}{ Total } & Tahun 2017 & 7,07 & 4,01 & 0,003 \\
& Tahun 2018 & 4,37 & 1,39 & \\
\hline
\end{tabular}

\section{HASIL}

Jumlah sampel total pada penelitian ini 1694 yang terdiri dari 600 sampel pada periode sebelum implementasi SIMERAH dan 1094 setelah implementasi SIMERAH. Tabel 1 memperlihatkan bahwa TAT Januari-Juni 2017 mempunyai nilai antara 2,13-18,55 jam dengan rerata 2,49 jam. Nilai rata-rata TAT Januari-Juni 2018 adalah antara
1,42-10,40 jam dengan rerata 4,37 jam. Terjadi penurunan TAT sebesar 25,2\% pada Januari-Juni 2018 bila dibandingkan dengan Januari-Juni 2017.

Tabel 2 dan grafik 1 menunjukan terjadinya penurunan signifikan TAT bulan pada tahun 2018 dibandingkan bulan yang sama di tahun 2017. Turnaround Time pada Januari turun dari 5,57 jam menjadi 4,46 jam $(\mathrm{p}<0,001)$, Februari dari 6,22 jam turun menjadi 4,40 jam ( $\mathrm{p}<0,05)$, Maret, dari 5,58 jam turun menjadi 4,36 jam $(\mathrm{p}<0,001) \mathrm{Mei}$, dari 6,01 jam turun menjadi 4,23 jam $(\mathrm{p}<0,001)$ dan Juni, dari 7,07 jam turun menjadi 4,37 jam $(\mathrm{p}<0,01)$. Turnaroud Time pada April juga terdapat penurunan dari 4,36 menjadi 3,33 namun secara statistik tidak signifikan ( $>0,05)$. Secara umum, TAT pada Januari-Juni 2018 signifikan lebih rendah dibandingkan TAT Januari-Juni 2018, yaitu 6,10 jam dibandingkan 4,37 jam ( $\mathrm{p}<0,001)$.

\section{PEMBAHASAN}

Pada penelitian ini ditemukan rerata TAT darah rujukan sebelum implementasi SIMERAH adalah 6 jam 10 menit dan setelah implementasi SIMERAH 4 jam 37 menit. Terjadi penurunan rerata TAT darah rujukan di Bank darah RSUP Dr. Wahidin Sudirohusodo sebanyak 25,2\% pada periode setelah menggunakan SIMERAH. Penurunan rerata TAT ini kemungkinan disebabkan karena pada tahun 2018 Bank Darah RSUP Dr. Wahidin Sudirohusodo telah menggunakan SIMERAH. SIMERAH menyebabkan petugas bank darah mengetahui persediaan darah di PMI dan telah memesankan darah sebelum merujuk keluarga pasien.

Rentang TAT pelayanan darah rujukan ke PMI di Bank Darah RSUP Dr. Wahidin Sudirohusodo pada tahun 2017 antara 2,13-18,55 jam dengan nilai rerata TAT 6,10 jam. Rentang TAT yang besar ini kemungkinan disebabkan oleh tidak tersedianya informasi ketersediaan darah sebelum keluarga pasien mengambil darah ke PMI, tidak adanya batasan waktu untuk mengambil darah, tingkat kesibukan di PMI, tidak tersedianya kendaraan dan lalu lintas yang macet. Rentang TAT pelayanan darah rujukan tahun 2018 adalah 1,42-10,40 jam dengan nilai rerata TAT 4,37 jam. Menurunnya rentang TAT pada tahun 2018 jika dibandingkan rentang TAT pada tahun 2017 kemungkinan disebabkan karena pada tahun 2018 petugas bank darah telah mengetahui ketersediaan darah di PMI dan telah memesankan darah melalui SIMERAH sebelum merujuk keluarga pasien ke PMI. SIMERAH juga memberi batas waktu 6 jam mulai dari pesanan darah disetujui oleh PMI sehingga darah diambil oleh keluarga pasien.

Hasil yang didapat pada analisis data perbulan menunjukan bahwa terjadi penurunan TAT yang 
signifikan pada bulan Januari, Febuari, Maret, Mei dan Juni. Bulan April 2018 terjadi penurunan rerata nilai TAT apabila dibandingkan dengan bulan April 2017 tetapi penurunan tidak bermakna secara statistik. Penyebab hasil yang tidak signifikan pada bulan April adalah jumlah sampel yang sedikit.

Total permintaan pelayanan darah rujukan dari Bank Darah RSUP Dr. Wahidin Sudirohusodo ke PMI dengan menggunakan SIMERAH pada bulan April 2018 adalah 556 permintaan. Jumlah permintaan darah rujukan yang disetujui oleh PMI adalah 350. Jumlah permintaan darah rujukan yang memenuhi kriteria inklusi dan eksklusi adalah 20. Penyebab sedikitnya jumlah tersebut adalah stok darah yang tidak tersedia, jaringan internet yang kurang baik, kepedulian petugas bank darah atau PMI yang masih kurang dan update data ketersediaan darah yang belum baik., ${ }^{1,6}$

\section{SIMPULAN}

Hasil penelitian ini menunjukan bahwa SIMERAH berhasil menurunkan TAT pelayanan darah rujukan ke PMI di Bank Darah RSUP Dr. Wahidin Sudirohusodo. Diperlukan perbaikan kualitas jaringan internet yang digunakan untuk SIMERAH dan sosialisasi ulang kepada petugas PMI atau bank darah tentang pentingnya update data dengan baik dan benar untuk memaksimalkan implementasi pelayanan darah menggunakan SIMERAH.

\section{DAFTAR PUSTAKA}

1. Pedoman Pelayanan Bank Darah Rumah Sakit Umum Pusat Dr. Wahidin Sudirohusodo. Makassar: 2013.

2. SPO Sistem Informasi Manajemen Darah (SIMERAH) RSUP Dr. Wahidin Sudirohusodo. Makassar: 2017.

3. Kemenkes. Peraturan Menteri Kesehatan Republik Indonesia Nomor 83 Tahun 2014 tentang Unit Transfusi darah, Bank Darah Rumah Sakit dan Jejaring Pelayanan Transfusi darah. Jakarta: 2014.

4. Kemenkes. Peraturan Pemerintah Republik Indonesia Nomor 7 Tahun 2011 Tentang Pelayanan Darah. Jakarta: 2011.

5. Kemenkes. Peraturan Menteri Kesehatan Republik Indonesia Nomor 91 Tahun 2015 Tentang Standar Pelayanan Transfusi Darah. Jakarta: 2015.

6. WHO. Availability, safety and quality of blood products [Internet]. 2015. Diakes pada Juni 2018. http://apps.who. int/medicinedocs/documents/s19998en/s19998en.pdf

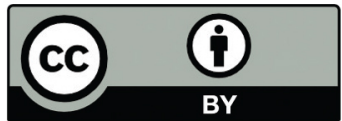

This work is licensed under a Creative Commons Attribution 